\title{
Russian Foolishness and Images of Fools in the Museum of Icons in Recklinghausen
}

\author{
O. A. Tuminskaya
}

State Russian Museum,

4, Inzhenernaya str., St. Petersburg, 191186, Russian Federation

For citation: Tuminskaya, Olga. "Russian Foolishness and Images of Fools in the Museum of Icons in Recklinghausen”. Vestnik of Saint Petersburg University. Arts 10, no. 1 (2020): 177-188.

https://doi.org/10.21638/spbu15.2020.109

Images of ascetics, which to a certain extent derive associations with Byzantine asceticism, can be found in Western European icons and murals. These are images of Fools-for-Christ. Images of persons clad in short-skirted garments, occasionally with symbols of their specific activities, such aspublic executioners, grave-diggers, and "the halt and the blind" are rare, although not unique. The similarity of garments and extraordinary symbols correlates with icons depicting "secular Fools-of-God," although carrying a wider emotional and semantic load. The surviving images of "odd-looking" characters in Western European sacred art of the $12-17^{\text {th }}$ centuries can be included in an individual established category known as "Kehricht der Welt" and presented as an outstanding phenomenon within the icon-painting repertoire of Christian artistic heritage. The article is devoted to the study of the image of Procopius and John of Ustiug Fool-for-Christ, who is one ofthe most popular old Russian saints, as well as the image of Saint Christopher Cynocephalus- the most famous Byzantine saint. Information about these blessed ones came to Russia as a result of the spread of literacy. Legends about various saints were brought by travelers and traders who regularly visited Constantinople and other countries. Attention to these saints led to writing about their lives lives and the creation of icons of saints. This situation is typical for Russian art of the Middle Ages $12-17^{\text {th }}$ centuries. Information about monuments of Russian and Cypriot icon-painting of the 15-17 $7^{\text {th }}$ centuries from the Recklinghausen Museum of Icons (Germany) is introduced.

Keywords: Fools-for-Christ, martyrs, Saint Procopius and Saint John of Ustyug, Saint Christopher Cynocephalus, Recklinghausen icon collection.

The Recklinghausen Museum of Icons features numerous monuments of Russian art. Among the exhibits are icons with images of Fools-for-Christ [1]. This is a rare category of holiness in the Russian Orthodox Church, so the icons featuring saint Fools-for-Christ are uncommon and a source of genuine interest for old art connoisseurs.

Russian Fools-for-Christ are successors of the Byzantine origin of Christian austerity. The perception of Foolishness for Christ in graphic art manifested itself in the iconography of these hermits. Icons of Fools-for-Christ are the merit of Russian people.

The surviving images of "odd-looking" characters in Western European sacred art of the $12-17^{\text {th }}$ centuries can be attributed to an individual established category known as "Kehricht der Welt" [2].

(c) Санкт-Петербургский государственный университет, 2020 
Several icons featuring "odd-looking characters" are exhibited in the Recklinghausen Museum of Icons. These icons include: "Holy Fools-for-Christ Procopius of Ustyug and John of Ustyug" (late $17^{\text {th }}$ century, Russia); "July Holidays and Saints" (late $17^{\text {th }}$ century, Russia), and the "Holy Doors" (late $15^{\text {th }}$ century, Crete).

Images of Fools-for-Christ of the late $14-19^{\text {th }}$ centuries have been identified and a list of the names of Fools-for-Christ has been compiled based on the existing burial places of these Christian hermits or location of their relics in churches. The main focus is made on the established iconographic version of the image of a Fool-for-Christ reproduced in icons or other worship artifacts of our ancestors. Each image has been described and supplemented with information on the iconographic version of the particular saint. The peak of worship of Fools-for-Christ in Rus' in the latter half of the $16^{\text {th }}$ century has been determined, and, therefore, the timeframe for selection of images of Fools-for-Christ has been established between the late $15^{\text {th }}$ and early $17^{\text {th }}$ centuries. However, love for history, promotion of literacy in Rus', devotion to reading about the lives of saints, establishment of icon-painting schools or shops in towns of special worship of local saint Fools-for-Christ along with some other historical and cultural factors had an impact on the extension of icon-painters' attention to images of Fools-for-Christ until the $19^{\text {th }}$ century.

A Fool-for-Christ was generally depicted nude or semi-nude. He would hold some attribute in his hands (a stick, a poker, a crucifix, or a staff) and was represented bare-headed with wild hair.

Information on the Fools-for-Christ (22 names) whose relics had been approved by the church and places of custody are known and has been compiled. The relics are stored in monstrances. The Fools-for-Christ are painted on icons and they are placed next to the relics. These icons could have been painted by local artists [3].

The earliest known icon depicting a Fool-for-Christ, having survived since the Middle Ages, is the icon "Procopius of Ustyug" which dates to the late $15^{\text {th }}$ century, although the first Fool-for-Christ known in Rus' was Andrew of Constantinople [4, p.316-31, colour plates $20^{\text {th }}-21^{\text {st }}$. The icon "Andrew of Constantinople and His Life in 18 Scenes" is dated to the early $16^{\text {th }}$ century and is stored in the collection of the Russian Museum [5, p. 122-3]. The logic of this choice is obvious. The facts of the life of Saint Andrew of Constantinople, who was not a national Fool-for-Christ, were of tremendous and paramount importance for the entire hagiographical and fact-of-life structure of the phenomenon of Russian Foolishness-for-Christ during the Middle Ages [6]. Next, the Fools-for-Christ follow who pursued their religious life in the Southern, Central and Northern Russia and in Siberia. Abraham of Smolensk, of the first known Fools-for-Christ of Southern Russia (proximity to Kiev, an apostolic city of Russian Christianity) whose popular and meticulously detailed life recorded by his contemporary has survived until our days, can be regarded as a spiritual guide for the succeeding ascetics who selected this form of self-dedication to the Christian church. Yet, scholars refer to him as a Fool-for-Christ with caution, defining the key propaedeutic function of Saint Abraham as imitation, completion of the rite of severe obedience and making strict vows.

In the context of Old Russian art as an integrated process, it covers a span between the $15^{\text {th }}$ and $17^{\text {th }}$ centuries. In the early specimen (Abraham of Smolensk and Michael of Klopsk) we observe the iconography of the venerable friars that were just "tasting" and "trying on" Foolishness-for-Christ, so in the icons they remain wearing friar habit. In later specimens, Foolishness-for-Christ was expressed to the full extent. In the icons similar- 
ity of this act referred to as "in Christ," not only in the religious but in the icon-painting context as well, is apparent. The Fools' similarity to Christ is embodied in the principal topics relating to the terrestrial life of Jesus Christ - the Theophany, the Agony in the Garden, the Crucifixion, - and it is only then that the idea of non-possession and carnal neglect for the sake of spiritual exaltation is manifested in the images of Basil the Blessed and Maxim of Moscow. In icons these saints are frequently depicted totally nude, similarly to Jesus Christ in the Epiphany and Crucifixion scenes. Later images painted during the Middle Age Rus' (Andrew of Totma and Simeon of Verkhoturye) reflect the position of social simplification and suggest the influence of peasant icon painting shops.

Icons depicting Fools-for-Christ became more popular at the turn of the $17^{\text {th }}$ century and were painted not only in Moscow, but in all places where the holy Fools toiled, provided an icon-painting shop existed there [7, p.29]. This period is associated with the secularization of sacred art, which should be considered as a position of active education of the laymen using visual equivalents of liturgical texts, rather than mere simplification.

Regional distribution is described below. Originating from Byzantine, Foolishness-for-Christ "settled" in the south of Rus' - Kiev and Smolensk (11-13 ${ }^{\text {th }}$ centuries). However, due to the domination of literature in the Byzantine art culture, in Kiev and Smolensk areas of Rus', Foolishness-for-Christ just began to take root and was reflected in the hagiographical descriptions, without graphic reflection of the extraordinary act of asceticism. Gradually, Foolishness-for-Christ began to grow stronger, acquire national identity and spread northward, so its most distinct feature was reflected in the unprecedented combination of humility and provocation. This oxymoron is typical for the Novgorod phase of Foolishness-for-Christ in Medieval Rus' (14 $4^{\text {th }}$ century). Novgorod Fools-forChrist expressed an understanding of their vows in the form of imitating persecution and safeguarding the sacred territory. All the acts of the Nicholas Kochanov and Theodore of Novgorod tandem consisted in the exploration of the sacred space. Their successor Arsenius of Novgorod was a more peaceful specimen of a "reverend Fool-for-Christ." The Rostov and Moscow versions of Russian holiness of Fools were the only ones featuring the most representative combination of realities of their abidance, life and depiction in icons. The number of icons of Fools-for-Christ increased in the 80 s of the $16^{\text {th }}$ century. This tendency existed until the mid- $17^{\text {th }}$ century.

The worship of holy Fools is designated by the beginning of the construction of the chapel dedicated to Procopius of Ustyug (1471) whose life style matched the definition of Foolishness-for-Christ above all else: having left the paternal home, a vagabond life, tolerance to abuse by locals and saying constant prayers for them and a talent of prophecy. In 1495, the residents of Ustyug built a church dedicated to him and, therefore, he must have been officially canonized by then. The first decades of the $16^{\text {th }}$ century are the period when two icons depicting Fools-for-Christ are dated: an early $16^{\text {th }}$ century icon "Procopius of Ustyug" from the Tretyakov Gallery [8, p. 230], and another icon dated mid-16th century from Uslavtsevo village depicting Maxim of Moscow and Isidore Tverdislov of Rostov [9, p. 54]. The phenomenon of Foolishness-for-Christ ended with the encyclical decree of patriarch Joseph forbidding the demonstration of Fools-for-Christ in churches, i. e. in 1646. Data on later images of medieval holy Fools are dated to the $19^{\text {th }}$ century.

The methodology for the Stroganov school manner analysis was established in the Northern icon catalogue. A Stroganov icon exhibition was held in 1923 in the Russian Museum and it was organized by P.N. Neradovsky and N. I. Sychev [10, p. 1]. This exhibi- 
tion marked the beginning of studies of Stroganov icons and embroidery by Russian art historians. It was highly appreciated by professionals.

The need for a Stroganov school exhibition had been felt for quite some time. In the 1920s, when the name of Stroganov was associated with the colonization of Perm and exploration of Siberia and their historical and cultural role was carefully reviewed, when, on the other hand, the entire period of origination and development of the famous "Stroganov icon-painting" and some historical characters was reassessed, an exhibition of Stroganov school icons became an urgent issue.

The images of ascetics in German museum collections feature a special minuteness of drawing. For example, the Recklinghausen Museum of Icons possesses quite an extensive collection of images of these saints such as the Holy doors depicting the Communion of Mary of Egypt. The painted leaf panels of the Holy doors from the Recklinghausen collection must have been made in Spain around the $15-17^{\text {th }}$ century, according to their dating, and their overall pattern consists of pointed conical shapes and duplicating curvature of arch crowns. The Venetian influence is obvious in this case.

The number of icons with images of "strange saints" exhibited in the museums is worth noting: six icons of Saint Christopher, the famous "Saint Procopius and Saint John of Ustyug" from the Stroganov school, the "Intercession" depicting Andrew the Fool-forChrist, Saint Simeon Stylites, Saint Mary of Egypt and Saint Nicolas Kochanov in a July calendar icon. All these icons are of high artistic quality and feature individual iconographic composition. Provided below are the descriptions of some of them.

1. Saint Alexis Man of God and Saint Mary of Egypt.

2. The icon "Saint Procopius and Saint John of Ustyug", the main item in the group of "strange saints" from the collection of the Recklinghausen Museum of Icons.

3. The icon "Menaion. July" depicting Saint Blessed Nicolas Kochanov.

The Holy doors depicting Mary of Egypt are narrow and crowned with acanthus leaves (preserved partially). The space of the leaf panels is split into two sections. The upper (smaller) sections depict Archangel Michael (left leaf) and Archangel Gabriel (right leaf) holding their typical attributes and wearing their traditional garments. Archangel Gabriel holds a sphere depicting Christ-Emmanuel. The figures are painted en face and half-length. The lower section features knee-high figures of Venerable Zosimas holding a Eucharist chalice (left leaf) and Mary of Egypt prepared to take the Eucharist (right leaf). The background is coated in gold. Analogies: doors of Khilandar monastery (latter half of the $10^{\text {th }}$ century), doors painted by Andreas Ritzos (?) (late $15^{\text {th }}$ century) from the Church of Saint George the Victorious on Patmos.

The icons "Saint Mary of Egypt" and "Saint Alexis Man of God" (fig. 1) feature a composition of two ascetics facing each other and praying to Lord Sabaoth whose image is depicted above. The sun and the moon to the left and to the right of the cloud symbolize the night of the Crucifixion. The garments of the saints feature multiple folds. The earth consists of red hills decorated with flowers. The central area of the icon contains bilateral quotations from the lives of Saint Alexis Man of God (on the left side) and Saint Mary of Egypt (on the right side). All these elements indicate that the icon originates from an OldRite icon-painting shop.

The icon "Saint Procopius and Saint John of Ustyug," the main item in the group of "strange saints" from the collection of the Recklinghausen Museum of Icons. The icon 


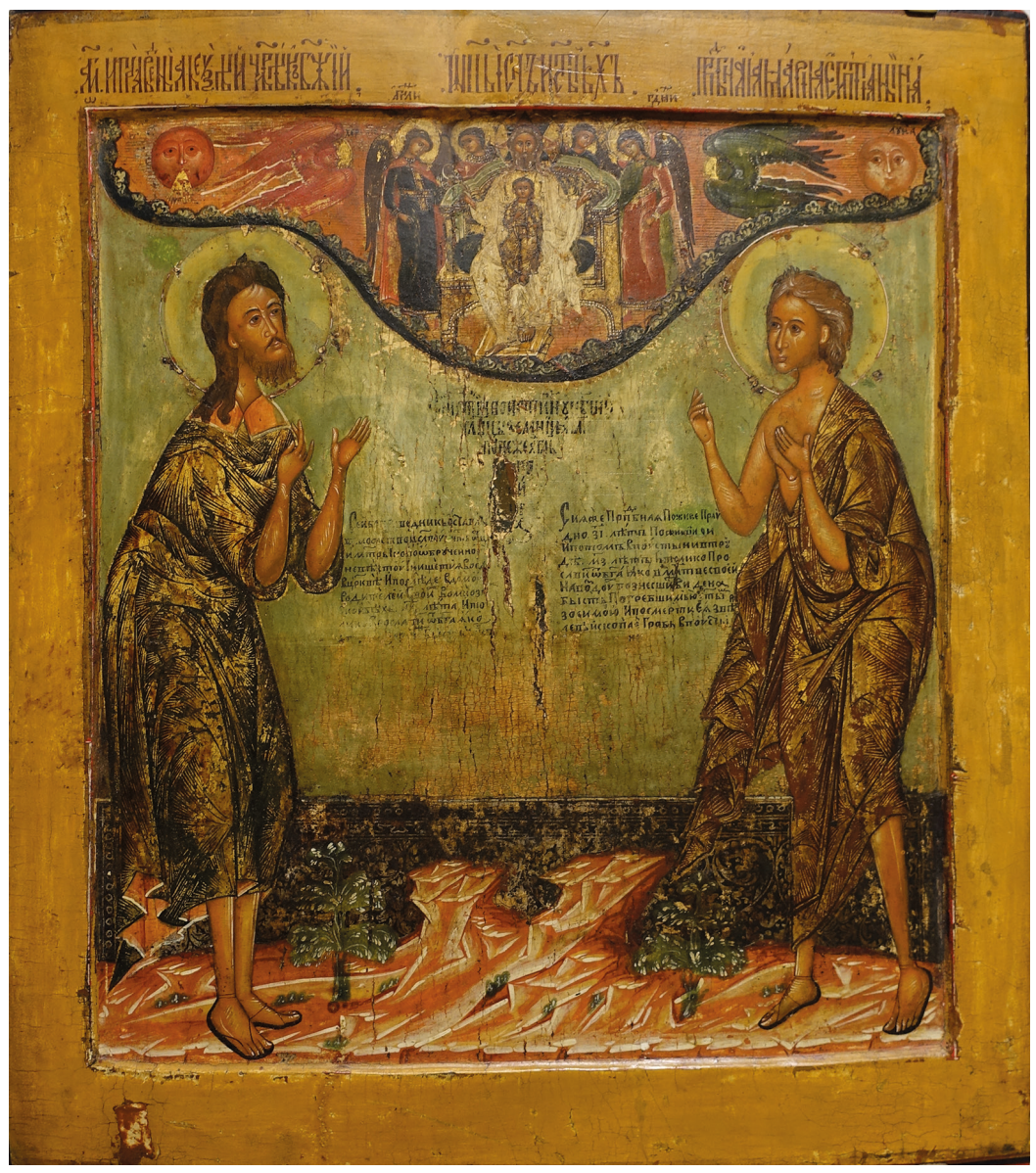

Fig. 1. Icon of "Saints Alex the Man of God and Mary of Egypt". Russia. The middle of the $17^{\text {th }}$ century. Museum of icons in Recklinghausen

"Saint Procopius and Saint John of Ustyug" from the Recklinghausen Museum of Icons is dated to the $17^{\text {th }}$ century and was painted in the Solvychegodsk area (fig. 2). It is a typical specimen of the Stroganov icon-painting school [11]. Stylistically, this icon belongs to Stroganov icon-painting school. Most likely, it was painted in Solvychegodsk or by a leading Ustyug artist, trained in the style of Stroganov school icon painters. Stroganov icon-painting style is manifested in the combination of colours where red shades prevail, application of gold coating in coloristic combinations, elongated figures, small heads and sentimental attention to the landscape. "Meticulously painted figures with small heads, short-skirted garments and excellent drawings are typical of the Ustyug icon-painting school from that period. The hills are shown in a conventional manner, with cut steps and wonderful flowers. The preciousness of painting, the artists ignored the looks of the saints that others found shocking. This demonstrates the relation of the artists to the Stroganov school" [12, p. 72].

The icon "Saint Procopius and Saint John of Ustyug" features the purple, dark red and pink colours that are typical for the above-noted northern region. In particular, such 


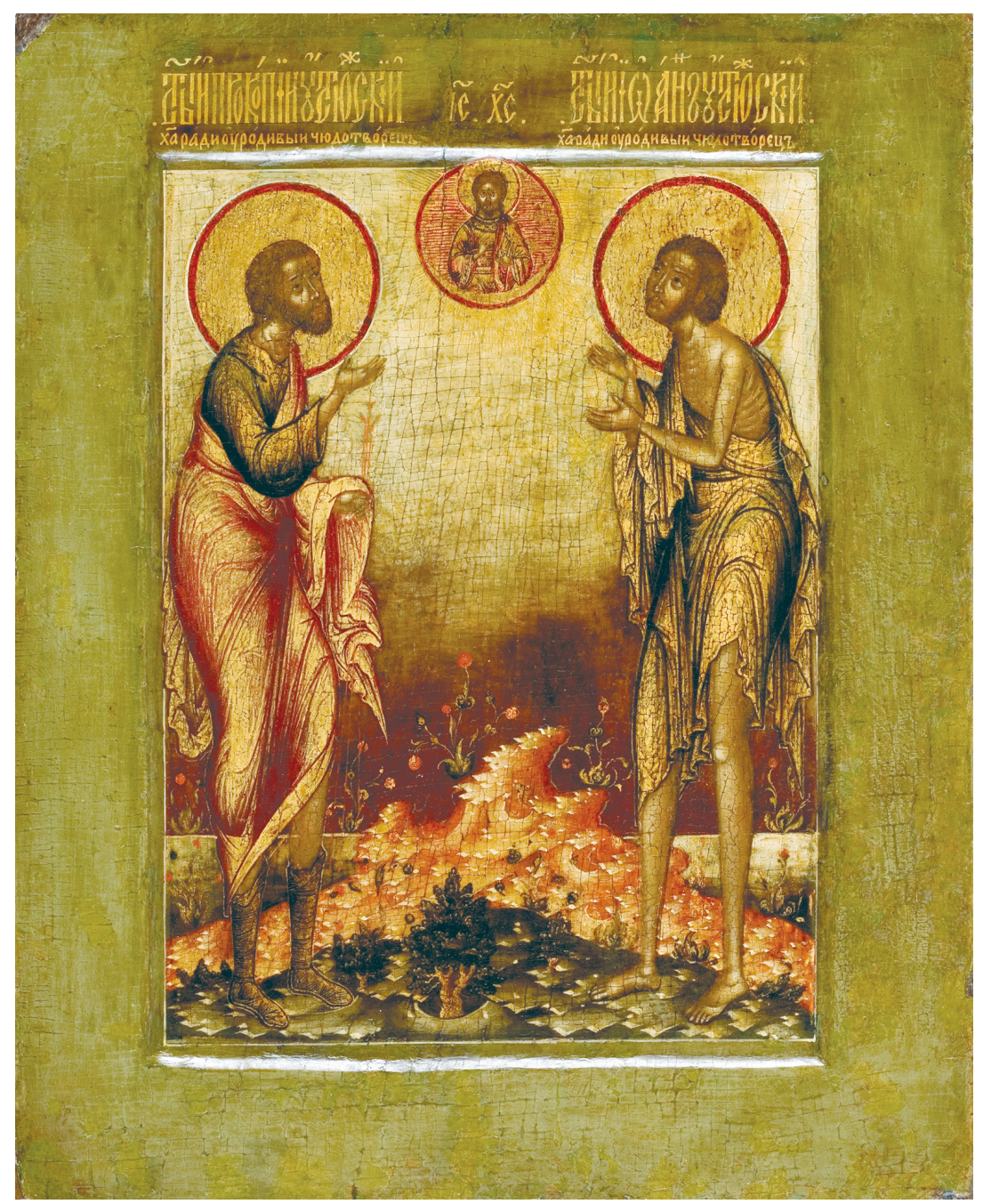

Fig. 2. Icon of "St. Procopius and John of Ustyug". Russia. Second half of the $17^{\text {th }}$ century. Museum of icons in Recklinghausen

"rubia" and "reft" (dark grey) tones became a standard for northern icons and was used by P.N. Filonov in his paintings.

The olive green frame (wide margins) bordering the icon attracts attention. It contains text that is written in rubia and gold.

A typology of the text on this icon has been made. This typology was described in detail in T. Daiber's thesis and published in the "Monumenta linguae slavicae dialecti veteris" edition [13, p.9]. The texts are written with the use of titlos: "СВЯТЫЙ ПРОКОПИЙ УСТЮЖСКИЙ (SAINT PROCOPIUS OF USTYUG) ॥ IC XC (JESUS CHRIST)|| СВЯТЫЙ ИОАНН УСТЮЖСКИЙ (SAINT JOHN OF USTYUG)".

The left-sided area of the icon represents hills and magnificent flowers resembling the Garden of Eden. Minute landscape details are one of the typical features of the Stroganov school icons. 


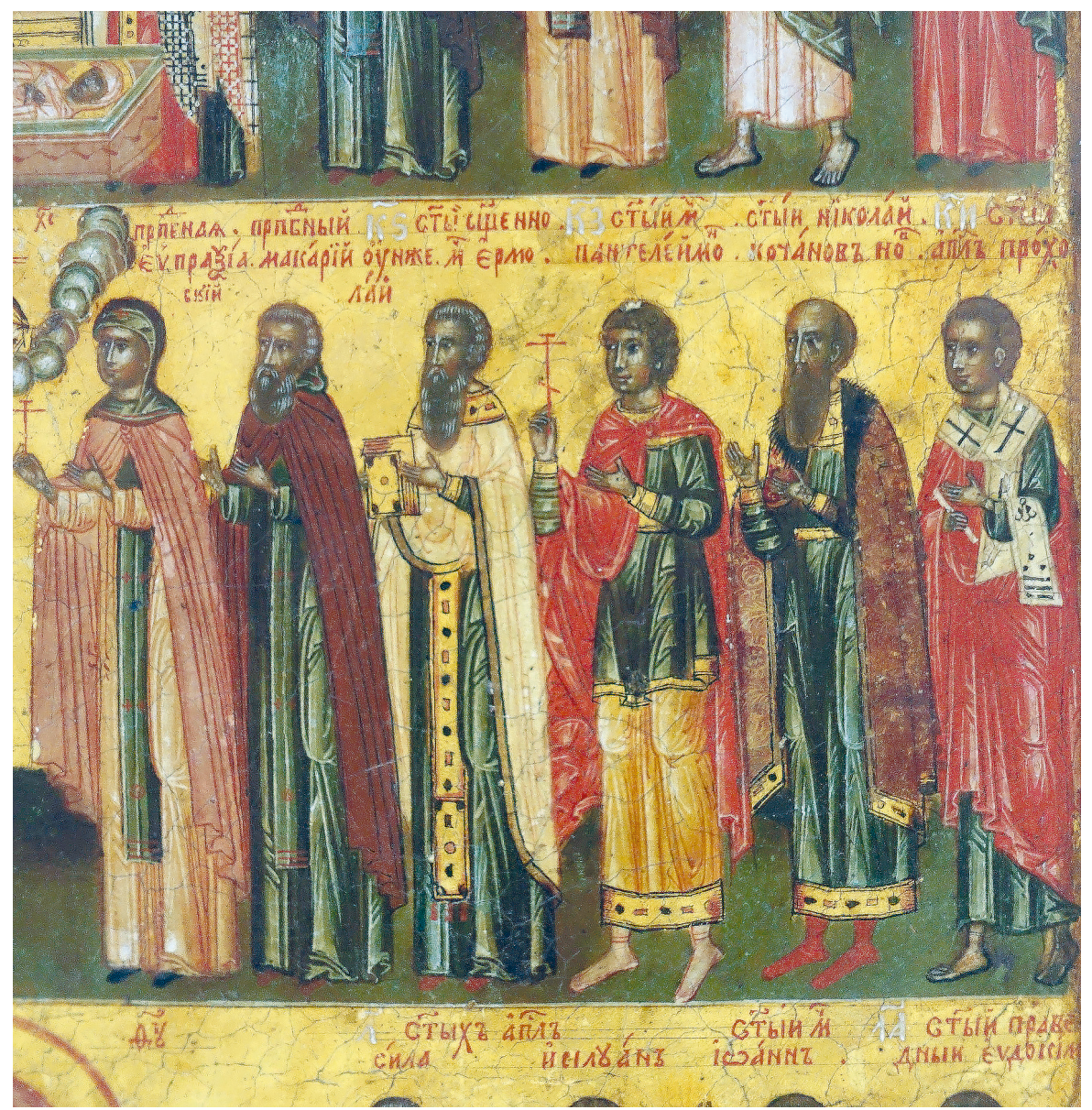

Fig. 3. Icon of "The Saints. July" with the image of St. Nicholas Kochanov. Russia. The middle of the $17^{\text {th }}$ century. Museum of icons in Recklinghausen

The icon "Menaion. July" under number 27 (second from right to left in the central row) represents Saint Blessed Nicolas Kochanov. He is dressed like a prince: a fur coat, a long shirt and tall boots. It is a very rare image of a Novgorod saint (fig. 3).

The practice of depicting saintly men of God did not fade away with the decree forbidding demonstration of Fools-for-Christ to attend churches (1722), and they continued their existence in conditions that were somewhat different, which means that people continued to commission icons with their images. A vast collection of images of Fools-forChrist can be found in the Old Rite art. German art historians actively explore the images of saints belonging to the "Kehricht der Welt" category. It is worth noting the long-standing and strong cultural tradition of Germany and Russia, and the existence of icons depicting Fools-for-Christ and other "strange saints" illustrate this.

The subject of topography concerning the lives of Fools-for-Christ is actively explored by scholars of philological disciplines from the Institute of Russian Literature (Pushkin House), specifically, by A. N. Vlasov [14, p. 263-72], N. V. Ponyrko [15, p. 22030], T.R.Rudi [16, p.84-92; 17, p.40-55; 18, p.123-4; 19, p.59-101]. However, the 
problems of graphic topography of Fools-for-Christ remain poorly explored, although they did attract the attention of international scholars. In Germany, constant attention to icons with images of "strange saints" or "odd saints" (eigentümlich Heiligen) has been recorded.

This fact is evidenced by bibliographic publications [20] describing icons with images of Fools-for-Christ $[21 ; 22]$ and conferences held in the recent years covering the problems related to the topography of Foolishness-for-Christ in art (Europa-Universität Viadrina Frankfurt a./O. Trialog: Deutsch - Polnish - Russischen wissenschaftliches Kooperations - project. 2013-2015). Unquestionably, the focus on asceticism in Eastern Christianity and images of "strange saints," some of which depict Fools-for-Christ, is of relevance in Western Europe. This publication is focused on the series of little known images of Fools-for-Christ and other ascetics from the Middle Ages contained in 12$17^{\text {th }}$ century art.

The earliest known item in the publication presented is "Condemnation and Martyrdom of Saint Lawrence." This image of Saint Lawrence definitely belongs to the series of ascetic images depicted within an individual icon-painting program. The young Christian martyr can be recognized by his childish round face and his symbol, a gridiron, in his hands (symbol of martyrdom).

His image is depicted on an enameled Trecento chalice. "The figure of the young beardless martyr Lawrence holding a gridiron in his hands can be easily identified among other unknown saints on the 'pommel' of the vessel $\langle\ldots\rangle$. The proportions, embossing patterns and types of enamel plaquettes of this liturgical vessel resemble the artwork of Sienna jewelers from the mid-and late $14^{\text {th }}$ century" [23, p. 154, colour plate XVII]. The colour and style of Lawrence's garments are clearly visible in the colour plate. He is wearing a high-neck garment of ripe cherry colour with an emerald roll collar. Two contrasting colours are popular in the enamel work, yet in this specific case the artist's reference to the irregularity and antinomy of the representation of the saint belongs to the martyrologic series of images.

The rarely seen short-skirted attire from the Middle Ages and an even more rare presentation of characters are to some extent marginal in the entirely liturgical medieval art. These are executioners represented on the panel from the chest depicting the execution of Saint Stephen (1210s). The panel decorated the top side of the lid of the chest portraying the martyrdom of St. Stephen (Saint-Étienne in the French tradition) [24, p. 78-9, № 19]. The figure seated on the throne is Saul, the future Apostle Paul [25, p. 401-30], is wearing a crown, probably by mistake. The standing haloed figure is Saint Stephen. The other figures wearing short-skirted bliauds are the executioners; the figure on the right side is placing clothes in front of Saul, while the figure on the left side is carrying stones, the instrument of torture. Esphyr Lapkovskaya [26, p.25-8], even in her stylistic reference to another chest depicting the martyrdom of Saint Stephen from the Vatican Museums [27, p. 28], was convinced that the panel represented Pontius Pilate washing his hands (a servant is handing him a towel), with the beardless Christ with a halo in front of him and a "messenger of Pilate's spouse" standing behind him.

Another sample of artistic transformation of characters can be found in tomb paintings in a Roman style church in Germany. This is the image of Longinus. The paintings in St. Mary's Church in Soest are dated to the $13^{\text {th }}$ century [28, p. 14-5]. Most probably, it was repainted later. Direct association of the tomb with the Jerusalem model is evident 


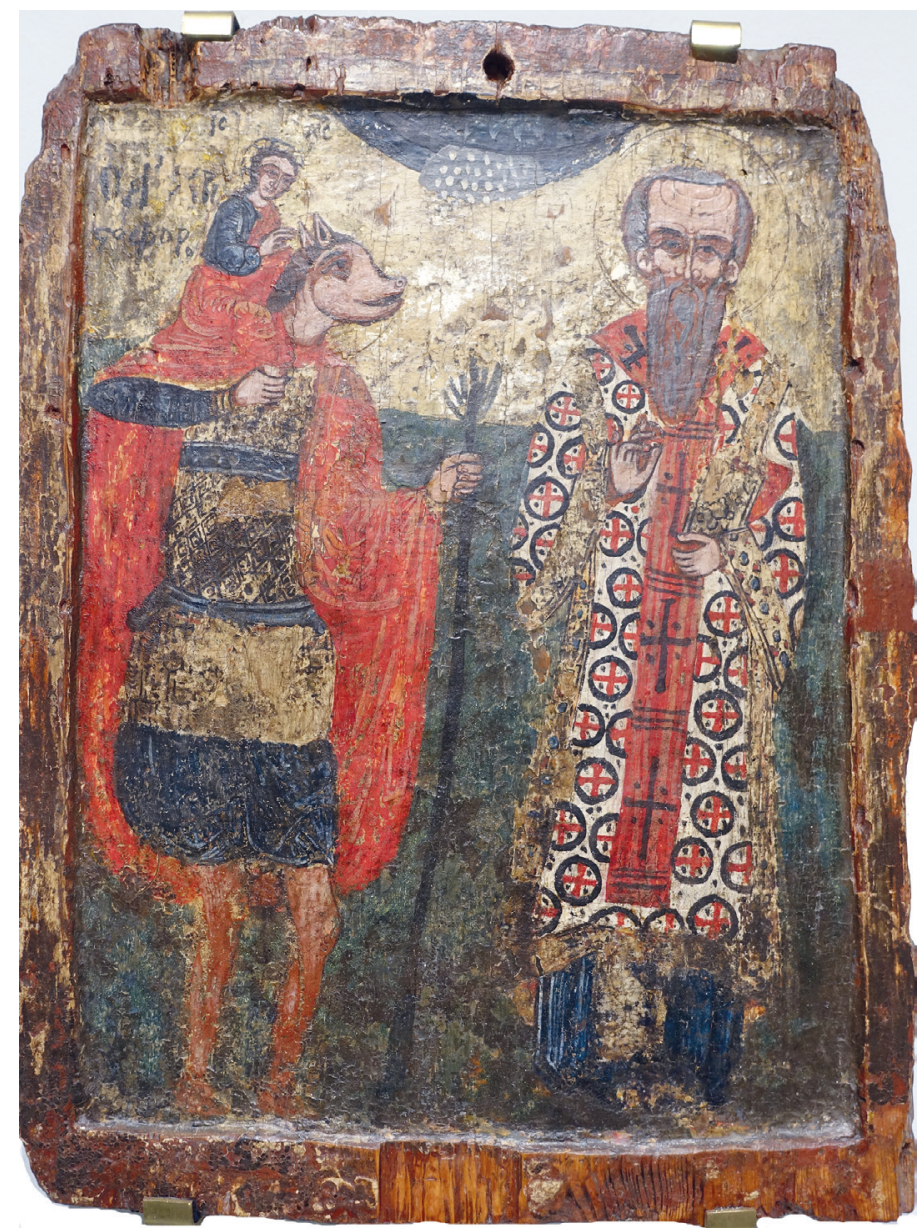

Fig. 4. Saint Christopher Cynocephalus and the Holy Bishop Charalampos. Greece. The first half of the $17^{\text {th }}$ century. Museum of icons in Recklinghausen

[29, p. 14]. The paintings in the tomb niche are dated 1240 and depict Bible scenes between Christ's Death and Ascension. Below the window is the image of Christ Crucified. "To the left is Captain Longinus with a lance (Links davon der Hauptmann Longinus mit der Lanze)" [28, p. 4]. The ascetic image topos is enhanced topographically by its location within the church: near the tomb, just above the centerline, facing upwards. An analogy is the image of Christ in the Pskov icons "Descent into Limbo," where a collateral semantic theme is defined.

"Saint Christopher Cynocephalus" [21, fig. 14] is depicted in still motion, facing the blessing Christ (fig. 4). A baroque compositional influence can be felt in this Greek icon dated to the early $18^{\text {th }}$ century. The icon features an abundance of red colour and a broad green earth. Saint Stephen is depicted en face, while Saint Christopher is represented sideways. Analogies in Russian icon painting can be found in the icon "Sophia the Holy Wisdom, the Paternity and Selected Saints" from the Tarnog district of Vologda region described in "Vologda icons" by A. A. Rybakov [30, cat. no. 263-264]. The 
bottom row of the icons depicts Maximus and Basil the blessed and Saint Christopher Cynocephalus. This migration of theme and image suggests a close association with sailors from Northern Russia and with Western Europe, the possible origin of worship of this "strange saint."

In the analysis of the phenomenon of iconography of Russian Fools-for-Christ the following important aspects must be noted: a) Russian Foolishness-for-Christ originated from the Byzantine source and is closely related iconographically; b) icon-painted nakedness originates from the Classic representation of figures and integrates it into stories related to the tragic events of the New Testament; c) the image of the "despised" originating from sculptural images on the Acropolis of Athens (particularly, the Lesser Attalid Dedication) is an important subject in iconography and icon-painting of Foolsfor-Christ.

Close associations between the image of a Fool-for-Christ and the images of the despised and the outcast in Classic sculpture are apparent. Thus, the Lesser Attalid Dedication (the $3^{\text {rd }}$ century B. C., Athens) includes an entire cycle of sculptures of the dying and the defeated [31]. At the end of the $19^{\text {th }}$ century, A. Michaelis [32, p. 119-25] pointed out the absence of any figures of winners among the surviving sculptures. All Greek deities and soldiers reflect the theme of the outcast and the despised. Wounded, yet not defeated and retaining their own dignity, they prefer death to enslavement. The theory of T.Halsher discloses the circumstances of the primary focus of the Lesser Dedication: "originally, the winner was not intended to be included in the composition" [33, p. 129]. This was an unprecedented interpretation in the Classic tradition [34, p. 120-36]. Subsequently this theme merged into the practice of mortification of flesh in Christian asceticism (the $6-9^{\text {th }}$ centuries) and was developed in the image of the Fool-for-Christ in the Middle Ages of Russian art (the $14-15^{\text {th }}$ centuries) [35, p. 290-4], having a close connection with the art of Byzantium [36].

To conclude, I would like to point out the scene of a "Beggar and a Dog," which is popular in the cathedrals of Dresden and Prague, yet is rare in Russian art. Saint Roch - protector from the plague (1477-1479). In iconography, the image of a beggar with a dog pointing at his wounds and sores became popular in the latter decades of the $15^{\text {th }}$ century.

\section{References}

1. Haustein-Bartsch, Eva. Ikonen-Museum Recklinghausen. München: Deutscher Kunstverlag, 1995.

2. Ikonen Museen der Stadt Recklinghausen. 1000 Jahre orthodoxe Kirche in der Russland: 988-1988. Russische Heilige in Ikonen: Ausstellungskatalog, Hrsg. Fabricius Ullrich. Recklinghausen: Verlag Lokalpresse GmbH, 1988.

3. Tuminskaia, Ol'ga. Poverty of Christ's Love... St. Petersburg: OOO IPK “Beresta” Publ., 2013. (In Russian)

4. Tuminskaia, Ol'ga. "The Image of Andrei the Fool in the Byzantine and Russian Pictorial Tradition". In Trudy Gosudarstvennogo Ermitazha, ed. by Vera Zalesskaia and Elena Stepanova. St. Petersburg: Gos. Ermitazh Publ., 2015, vol. 74: Vizantiia v kontekste mirovoi kul'tury: materialy konferentsii, posviashchennoi pamiati A. V. Bank (1906-1984). (In Russian)

5. Lazarev, Viktor. Russian Iconography from its Origins to the Beginning of $16^{\text {th }}$ Century. $3^{\text {rd }}$ ed. Moscow: Iskusstvo Publ., 2000. (In Russian)

6. Moldavan, Aleksandr. The Life of Andrew the Fool in Slavic Writing. Moscow: Azbukovnik Publ., 2000. (In Russian) 
7. Pliukhanova, Mariia. Plots and Characters of Muscovy. St. Petersburg: Akropol' Publ., 1995. (In Russian)

8. Antonova, Valentina, and Nadezhda Mneva. Catalogue of Ancient Russian Art of the $11^{\text {th }}-$ Beginning of the $18^{\text {th }}$ centuries. The Experience of Historical and Artistic Classification. 2 vols. Moscow: Iskusstvo Publ., 1963, vol. 2: the $16^{\text {th }}$ - beginning of the $18^{\text {th }}$ centuries. (In Russian)

9. Mel'nik, Aleksandr, comp. Iconography of the Saints of Rostov: Exhibition Catalogue. Rostov: "Rostov Kremlin" Publ., 1998. (In Russian)

10. Sychev, Nikolai, and Russkii muzei: Khudozhestvennyi otdel. Exhibition of Works of Art "Stroganov School": Catalogue. Petrograd: Gos. tip. im. Ivana Fedorova Publ., 1923. (In Russian)

11. Kelley, Christopher, transl. and ed. An Iconographer's Patternbook: The Stroganov Tradition. Torrance CA: Oakwood Publications, 1992.

12. Haustein-Bartsch, Eva. Ikonen. Ikonen-Museum, Recklinghausen. Hrsg. Norbert Wolf. Köln: Taschen-Verlag, 2008.

13. Daiber, Thomas. Aufschriften auf russischen Ikonen. Freiburg im Breisgau: Weiher, 1997.

14. Vlasov, Andrei. Hagiographic Novels and Tales of Holy Fools Procopio and John of Ustiug. Ed. by Gelian Prokhorov. St. Petersburg: Oleg Abyshko Publ., 2010. (In Russian)

15. Ponyrko, Natal'ia. "The Author of the Verses of Repentance and Chant Whacky Stefan". In Institut russkoi literatury (Pushkinskii Dom) RAN. Trudy Otdela drevnerusskoi literatury, ed. by Oleg Tvorogov, 220-30. St. Petersburg: Dmitrii Bulanin Publ., 2003, vol. 54. (In Russian)

16. Rudi, Tat'iana. "Righteous Wives of Ancient Russia". Russkaia literatura, no. 3 (2001): 84-92. (In Russian)

17. Rudi, Tat'iana. "Medieval Hagiographic Topic: (Imitatio Principle and Problems of Typology)". In $L i-$ teratura, kul'tura i fol'klor slavianskikh narodov: XIII mezhdunarodnyi s"ezd slavistov (Liubliana, 2003): doklady rossiiskoi delegatsii, comp. by Lidiia Sazonova, 40-55. Moscow: IMLI RAN Publ., 2002. (In Russian)

18. Rudi, Tat’ana. "Imitatio Christi". Die Welt der Slaven 48, H. 1-2 (2003): 123-34.

19. Rudi, Tat'iana. "Topic of Russian Lives (Typology Issues)". In Institut russkoi literatury (Pushkinskii Dom) RAN. Russkaia agiografiia. Issledovaniia. Publikatsii. Polemika, ed. by Svetlana Semiachko, 59101. 3 vols. St. Petersburg: Dmitrii Bulanin Publ., 2005, vol. 1. (In Russian)

20. Ottovordemgentschenfelde, Natalia. Jurodstvo: eine Studie zur Phänomenologie und Typologie des "Narren in Christo". Jurodivyj in der postmodernen russischen Kunst. Frankfurt am Main: Peter Lang, 2004.

21. Winkler, Martin. Heilige und Heiligenleben. 3 Aufl. Recklinghausen: Verlag des Landkreises Recklinghausen, 1959.

22. Haustein-Bartsch, Eva, und Konstantin Ugrinov. Wunder des Lichts. Ikonen aus Recklinghausen und Varna: Ausstellungskatalog. Dordrecht: Elsevier B. V., 2014.

23. Solov'eva, Larisa. "The Italian Chalice with Basse Taille Enamel Made by the Goldsmith of Siena of the XIV Century from the Hermitage Museum". In Iuvelirnoe iskusstvo i material'naia kul'tura: sbornik statei, comp. Viktoriia Kidzhi, Irina Paskacheva, Nikita Tsarev, 154-61. St. Petersburg: Gos. Ermitazh Publ., 2017. (In Russian)

24. Nekrasova, Ekaterina. The Azur and Gold of Limoges. Twelfth-to Fourteen-Century Enamels: Exhibition Catalogue. St. Petersburg: Gos. Ermitazh Publ., 2009. (In Russian)

25. Turdeanu, Émili. "La 'Vision de Saint Paul' dans la tradition littéraire des Slaves orthodoxies". Die Welt der Slaven 1 (1956): 401-30.

26. Lapkovskaia, Esfir'. Applied Art of the Middle Ages in the State Hermitage. Metal Products. Moscow: Iskusstvo Publ., 1971. (In Russian)

27. Stohlman, Friedrich. Gli smalti del Museo sacro vaticano. Città del Vaticano: Biblioteca apostolica vaticana, 1939.

28. Elbert, Dirk, und Ilse Maas-Steinhoff. Maria zur Höhe in Soest "Hohenkirche". München: Deutscher Kunstverlag, 2010.

29. Acheimastou-Potamianou, Myrtali, ed. Holy Image, Holy Space: Icons and Frescoes from Greece. Athens: Greek Ministry of Culture; Byzantine Museum of Athens, 1988.

30. Rybakov, Aleksandr. Icons of Vologda: Centers of Artistic Culture of the Vologda Land of the $13^{\text {th }}-18^{\text {th }}$ Centuries: Album. Moscow: Galart Publ., 1995. (In Russian)

31. Trofimova, Anna. The Fallen. The Dying gaul and the Lesser Attalides Dedication. From Nazionale Museo Archeologico, Naples. St. Petersburg: Gos. Ermitazh Publ., 2017. (In Russian) 
32. Michaelis, Adolf. "Der Schöpfer der Attalischen Kampfgruppen”. Jahrbuch des Kaiserlich Deutschen Archäologischen Instituts 8 (1893): 119-34.

33. Hölscher, Tonio. "Die Geschlagenen und Ausgelieferten in der Kunst des Hellenismus". Antike Kunst 28 (1985): 120-36.

34. Toporov, Vladimir. Holiness and Saints in Russian Spiritual Culture. 2 vols. Moscow: Gnozis Publ.; Shkola "Iazyki russkoi kul'tury" Publ., 1998, vol. 2: Tri veka khristianstva na Rusi (XII-XIV vv.). (In Russian)

35. Tuminskaia, Ol'ga. The Icon of the Holy Fool: (The Image of the Holy Fool in Christ in the Russian Fine Arts of the Late Middle Ages and Modern Times). St. Petersburg: Dmitrii Bulanin Publ., 2016. (In Russian)

36. Saenkova, Elena, comp. Masterpieces of The Byzantine Empire: Exhibition Catalogue. Moscow: Gos. Tret'iakovskaia galereia Publ., 2017. (In Russian)

Received: May 21, 2019

Accepted: November 28, 2019

Author's information:

Olga A. Tuminskaya - Dr. Habil.; olgmorgun@yandex.ru 